University of Arkansas, Fayetteville

ScholarWorks@UARK

Research Projects

Terrorism Research Center

$10-2021$

\title{
Gender and Criminal Justice Responses to Terrorism in the United States
}

Summer Jackson

California State University, East Bay

Jeff Gruenewald

University of Arkansas, Fayetteville, jgruenew@uark.edu

Katie Ratcliff

University of Arkansas, Fayetteville

Follow this and additional works at: https://scholarworks.uark.edu/tercpr

Part of the Criminology Commons, Criminology and Criminal Justice Commons, Gender and Sexuality Commons, and the Terrorism Studies Commons

\section{Citation}

Jackson, S., Gruenewald, J., \& Ratcliff, K. (2021). Gender and Criminal Justice Responses to Terrorism in the United States. Research Projects. Retrieved from https://scholarworks.uark.edu/tercpr/25

This Brief is brought to you for free and open access by the Terrorism Research Center at ScholarWorks@UARK. It has been accepted for inclusion in Research Projects by an authorized administrator of ScholarWorks@UARK. For more information, please contact scholar@uark.edu. 


\section{Gender and Criminal Justice Responses to Terrorism in the United States}

Summer M. Jackson, Katie Ratcliff, and Jeff Gruenewald

\section{SUMMARY}

This brief summarizes findings from a recent study published in Crime \& Delinquency titled "Gender and Criminal Justice Responses to Terrorism in the United States" (available at: https://doi.org/10.1177/00111287211047535). Using data from the American Terrorism Study (ATS), this study examines how gender varies across federal terrorism cases, how gender shapes federal terrorism case outcomes, and how combinations of relevant case attributes uniquely impact court outcomes for males and females.

Data include a sample of 2,147 defendants in terrorismrelated cases across several types of legal measures: charge type, number of charges, whether or not the prosecutor references terrorism (e.g., relying on terrorism statutes or referring to a defendant's association with a terrorist movement during adjudication), joint or single prosecution, bail, conviction outcome, and sentence length. While several types of analyses were conducted, only descriptive statistics are presented in this brief.

\section{FIGURE 1 \\ DATA OVERVIEW}

\section{American Terrorism Study DATA SOURCE}

Over 1,600 terrorism and terrorism-related federal court cases, 1980-present

\section{2,147 \\ DEFENDANTS}

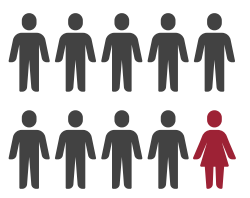

37 years

AVERAGE AGE
$90 \%$

MALE

\section{KEY FINDINGS}

\section{SIMILARITIES ACROSS GENDER}

Both male and female terrorism defendants tend to be charged with conventional, non-violent charges, and on multiple counts. Cases also tend to be prosecuted explicitly as associated with terrorism at similar rates across gender.

\section{DIFFERENCES ACROSS GENDER}

Female defendants are more likely to be indicted with others, more likely to receive bail, slightly less likely to be convicted, and receive shorter sentences. They also tend to be younger and are more often associated with radical environmentalist movements.

\section{EXTRALEGAL FACTORS AND JUDICIAL OUTCOMES}

In addition to gender, outcomes including the likelihood of receiving bail, likelihood of conviction, and sentence length are associated with extra-legal factors including ideology, age, and decisions to "politicize" prosecutions. 


\section{PERCENT FEMALE BY IDEOLOGY}

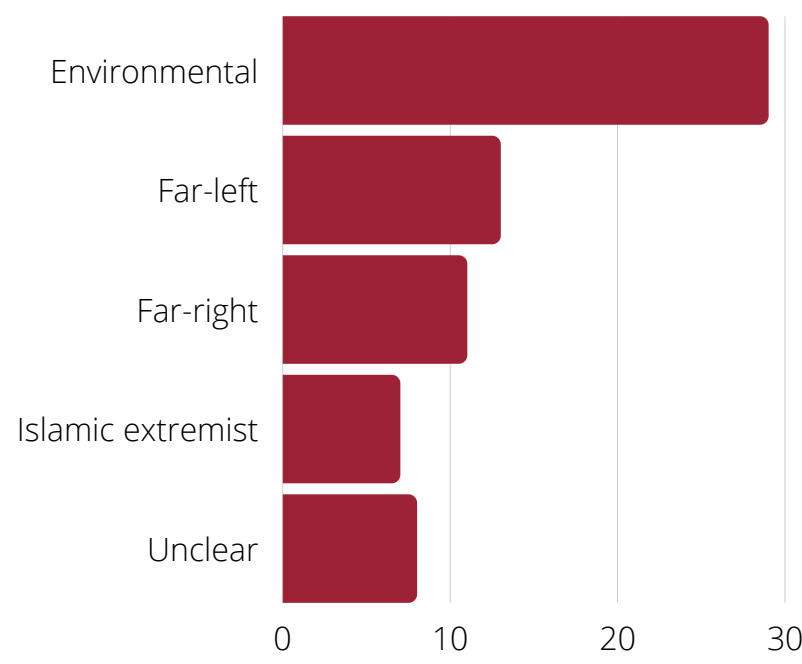

While the most common ideology in the sample for both males and females was Islamic extremist, females make up a higher proportion of the radical environmental movement, which includes groups such as the Animal Liberation Front (ALF) and Earth Liberation Front (ELF).

Males and females had similar conviction rates of over $\mathbf{8 0 \%}$, though males are slightly more likely to be convicted. Convictions are most likely (70\%) obtained through guilty pleas, rather than jury trials, for both males and females. Also, male and female defendants are similarly indicted on multiple counts and labeled as terrorists by prosecutors during adjudication, though males are more likely to be charged with terrorism and similarly charged statutes.

\section{FIGURE 3}

\section{LEGAL OUTCOMES BY GENDER}

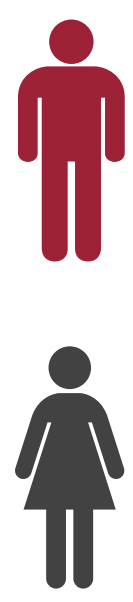

RECEIVED BAIL
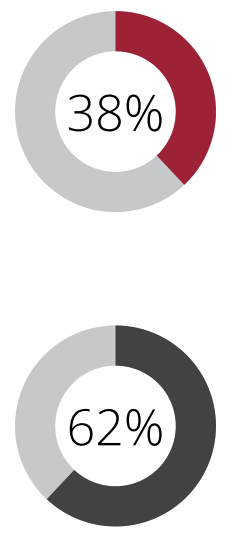

CONVICTED
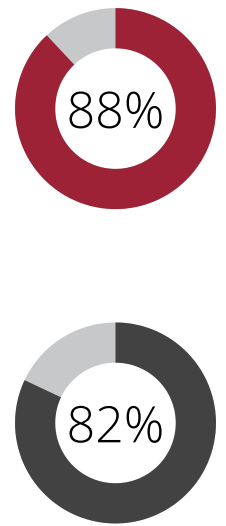

AVG. SENTENCE

INDICTED W/ OTHERS

\section{0 \\ MONTHS \\ 75 \\ MONTHS}

$77 \%$

\section{$65 \%$} $\min$

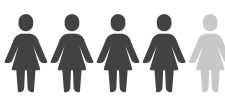

Previously reported gender disparities in criminal justice responses to conventional forms of crime suggest the need to also examine judicial outcomes across gender in other serious forms of crimes like terrorism. This study found that male defendants were indicted alone more often, received longer sentences, and received bail far less than their female counterparts. It is important to note that while these findings support notions that females are often treated more leniently by the criminal justice system, they do not take into consideration the varying roles that women play in terrorist organizations and the degree to which they engage in political violence.

Future studies should focus attention on the diverse roles these female offenders play in terrorist attacks, how these roles differ across ideologies, and how their group participation shapes criminal justice responses. 


\section{ABOUT THE TERRORISM RESEARCH CENTER}

The Terrorism ResearchCenter (TRC) is a non-partisan research organization located in Fulbright College's Department of Sociology and Criminology at the University of Arkansas. Their mission is to use the tools of social science and data analytics to promote safer communities, inform evidence-based policies, and train the next generation of researchers and law enforcement professionals. The TRC houses the American Terrorism Study (ATS), a collection of federal terrorism and terrorism-related court records dating back to the 1980s. More than 1,600 court cases and nearly 3,000 offenders are included in the ATS. Variables include legal and demographic measures, as well as geospatial and temporal markers of terrorism incidents and preparatory activities.

The TRC also houses the Bias Homicide Database (BHDB) and Human Trafficking Study (HTS) Database, collaborating with students and researchers at institutions across the country to study issues of terrorism and extremism.

The TRC introduced the Crime and Security Data Analytics Lab (CASDAL)_in 2020 to promote multidisciplinary research projects relating to crime and security issues, research partnerships with private and public agencies, and to train students in methods of crime analysis.

For more information about the TRC and our work, please visit terrorismresearch.uark.edu.

\section{ATS DEFINITIONS AND INCLUSION CRITERIA}

ATS case inclusion is based on one or more of the following: 1) official designation be FBI or other federal agency as a terrorism or terrorism-related indictment, 2) investigation into the case by the Joint Terrorism Task Force (JTTF), or 3) publicly known case details align with the FBI definition of terrorism: "The unlawful use of force or violence against persons or property to intimidate or coerce a Government, the civilian population, or any segment thereof, in furtherance of political or social objectives."

Additional definitions of ATS variables can be found at terrorismresearch.uark.edu.

\section{ABOUT THIS RESEARCH BRIEF}

\section{Contributors}

\author{
Dr. Summer Jackson \\ Citation \\ Assistant Professor \\ California State University, East Bay \\ Dr. Jeff Gruenewald \\ TRC Director and Associate Professor \\ of Sociology \& Criminology \\ Katie Ratcliff \\ TRC Associate Director \\ \& Research Program Manager
}

This brief summarizes research from a study recently published in Crime \& Delinquency. Original: https://doi.org/10.1177\%2F0011128 7211047535

\section{To cite this research brief:}

Terrorism Research Center. (2021). Gender and Criminal Justice Responses to Terrorism. Retrieved from terrorismresearch.uark.edu/rbgender-cj-responses. 